\title{
Molecular detection of Beta-lactamase blaCTX- $M$ group 1 gene in Escherichia coli Isolated from Drinking Water in Khartoum State
}

Hisham N Altayeb ( $\sim$ hishamaltayb@sustech.edu )

Sudan University of Science and Technology College of Science https://orcid.org/0000-0002-26359383

Eman Khalid

Sudan University of Science and Technology

Ehssan h Moglad

Prince Sattam bin Abdulaziz University

\section{Research}

Keywords: blaCTX-M-1 gene, ESBLs, Escherichia coli, drinking water, Sudan

Posted Date: May 7th, 2020

DOI: https://doi.org/10.21203/rs.3.rs-22974/v1

License: (9) (i) This work is licensed under a Creative Commons Attribution 4.0 International License. Read Full License

Version of Record: A version of this preprint was published at Journal of Water and Health on October 17th, 2020. See the published version at https://doi.org/10.2166/wh.2020.160. 


\section{Abstract}

\section{Background}

One of the most common challenges facing the world today is the rapid spread of antibiotic-resistant bacteria. According to current evidence, this is mainly as a result of presumed use of antibiotics, the interaction between humans or from animal sources. Still, there is limited focus on the role of environmental factors, especially water. This study aimed to detect the bla $a_{\mathrm{CTX}-\mathrm{M}}$ group 1 gene in Escherichia coli (E. coli) isolated from drinking water in Khartoum State.

\section{Methods}

Two hundred and eighty water samples were collected from different localities in Khartoum State and resources. Isolation and identification of $E$. coli performed by using lauryl tryptose broth, Brilliant Green Bile Broth, biochemical reaction, and culture characteristics on EMB media. Antimicrobial sensitivity tests were performed for all isolated bacteria using cefotaxime $(30 \mu \mathrm{g})$, gentamycin $(10 \mu \mathrm{g})$, tetracycline $(25 \mu \mathrm{g})$ and chloramphenicol $(30 \mu \mathrm{g})$ by agar diffusion method. DNA extracted by boiling method, bacterial genomic DNA used as a template to detect the bla $a_{C T X-M}$ group 1 gene by PCR.

\section{Results}

The result displayed that eighty-six (30.7\%) E. coli isolated out of two hundred and eighty water samples. Out of eighty-sixing isolated bacteria, 49\% (42/86) were from Khartoum locality, 28\% (24/86) were from Omdurman locality, and 23\% (20/86) were from Khartoum North locality. Antimicrobial susceptibility testing revealed that the highest resistant percentage was $59 \%$ for tetracycline, followed by $35 \%$ for gentamycin. While for chloramphenicol and cefotaxime were $22 \%$ and $20 \%$, respectively. CTX-M group 1 gene was detected in $40 \%$ of all isolates.

\section{Conclusion}

This study concludes that drinking water in Khartoum State might be contaminated with faces and be a possible source for the transmission of resistant bacteria to humans.

\section{Introduction}

There is global concern about antibiotic resistance phenomena with a serious significance on the treatment of infections, the increasing of this problem results from widespread uses or misuses of antibiotics in human medicine as well as veterinary and agriculture [1]. As a result, there is growing in the antibiotics resistance in the bacteria that cause community infections and hospital-acquired infections [2].

Previously, the infection by Escherichia coli (E. coli) had an effective antibiotic therapy; there were no signs of E. coli on morbidity, mortality, and health care, this condition has been altered due to 
accumulative of the occurrence of antimicrobial-resistant by E. coli [3]. Although beta-lactamase has been commonly used in the treatment of $E$. coli infection in both human and animal medicine, however, extended-spectrum beta-lactamase (ESBLs) producing E. coli increasing rapidly [4]. ESBLs belong to class A beta-lactamases, and their genes include TEM, SHV, CTX-M [5]. TEM and SHV genes were the most predominant type of ESBLs in 1990. Conversely, CTX-M genes frequencies raised recently and became the most dominant ESBL type worldwide [6]. CTX-M-type has been increasingly documented in gram-negative bacteria, predominantly in E. coli [7]. ESBLs enzymes were categorized into five major classes according to the similarities between their protein sequences as follows: CTX-M-1 cluster (CTX-M$1,-3,-10,-11,-12,-15,-28$ and FEC-1), the CTX-M-2 cluster (CTX-M-2, $-4,-5,-6,-7,-20$, and TOHO-1), the CTX-M-8 cluster (CTX-M-8), the CTX-M-25 cluster (CTXM- 25 and - 26), and the CTX-M-9 cluster (CTX-M-9, $-13,-14,-16,-17,-19,-21,-24,-27$, and TOHO-2) [8]. The CTX-M-1 group is the most prevalent CTX-M type worldwide [9]. In Sudan recently, there are increasing reports of CTX-M-15, in both hospital and community-acquired infections [10-12].

The presence of $E$. coli in drinking water or the environment is indicators for fecal contamination (Nourizadeh et al., 2013; WHO, 2012). Antimicrobial-resistant bacteria can contaminate the natural and drinking water sources by some human activities such as generating wastewater settlements, farms, and hospitals. Also, increase risk of groundwater contamination, as well as natural activities such as stormwater runoff, may be washed into rivers or groundwater since the soil contains bacteria as a result of using cow dung extensively as fertilizer [13]. Besides, the wastewater usage plant sites offer a promising situation for the multiplication of resistant bacteria [14]. Thus, water does not only serve as a reservoir for the distribution of antibiotic-resistant microorganisms among human and animal populations but also used as a system by which the resistance genes are presented into the natural bacteria ecosystem, spreading of resistant genes to non-resistant bacteria [14]. Ingestion of polluted water with antimicrobial-resistant $E$. coli can lead to the spread of resistant strains in humans [15]. Consequently, this will lead to a wide epidemic and endemic spreads of multidrug-resistant bacteria [15, 16].

In Sudan, there is no attention has been given to the potential role of drinking water in the dissemination of antibiotic-resistant bacteria in the population. Although evidence shows that it may be an essential pathway for genes transfer to human pathogenic and commensal strains [17]. This study highlights the possible role of drinking water in the transmission of antimicrobial-resistant bacteria to humans. Subsequently, this study aimed to detect the bla ${ }_{C T X-M-1}$ gene in $E$. coli bacteria isolated from drinking water in Khartoum State and determine their antimicrobial susceptibility pattern.

\section{Material And Methods}

\section{Study design and sample collection}

In this cross-sectional study, two hundred and eighty water samples were collected randomly from the three localities of Khartoum State (Khartoum 145, Khartoum North 70, and Omdurman 65), at a period 
from September to November 2017.

Water samples were collected under aseptic conditions from various water sources (taps water 160 and houses tanks 120). The open of the tap was sterilized firstly by burning around the pipe using a cotton swab moistened with alcohol to avoid contamination from the environment. Then the water was allowed to run down for 2 to 3 minutes, after that, we collected about $50 \mathrm{ml}$ from the taps and tanks into sterile screw-cap bottles containing about $50 \mathrm{ml}$ of lauryl tryptose broth media and an inverted Durham tube. Collected samples were transported immediately in plastic boxes with icepacks to the microbiology laboratory (Cheesbrough, 2005).

\section{Bacteriological Analysis}

The bottles which contain water samples and lauryl tryptose broth were incubated at $37^{\circ} \mathrm{C}$ for $48 \mathrm{hrs}$ aerobically. After incubation, the bottle with gas production was sub-cultured into two bottles containing Birilent Green Bile Broth (BGBB) media (Himedia, India) with Durham tube. One bottle was incubated for 24 hours at $37^{\circ} \mathrm{C}$ to detect the coliform, and the other bottle was incubated at $44^{\circ} \mathrm{C}$ to detect the presence of heat-tolerant coliform.

The presence of turbidity and gas in the Durham tubes was considered a positive test for coliforms. For isolation and counting of coliforms, $10 \mu$ from positive tubes were further cultured on eosin methylene blue (EMB) agar (Himedia, India) and incubated at $37^{\circ} \mathrm{C}$ for $24 \mathrm{hrs}$ aerobically. The appearance of green metallic sheen, gram stain, and biochemical tests was used for the identification of $E$. coli $[18,19]$.

\section{The antimicrobial susceptibility profile}

The antimicrobial sensitivity testing was conducted using the Kirby-Bauer disc diffusion technique. The following sets of antibiotic disks were used, cefotaxime $(30 \mu \mathrm{g})$, gentamycin $(10 \mu \mathrm{g})$, tetracycline $(25 \mu \mathrm{g})$, and chloramphenicol (30 $\mu \mathrm{g})$ (Himedia, India).

Susceptibility testing results were interpreted according to the clinical laboratory standards institute (CLSI) guidelines [20]. E. coli ATCC 25922 was used as quality control strains.

\section{DNA extraction}

DNA was extracted by the boiling method [21]. Firstly, a pure colony of E. coli was cultured on nutrient agar and incubated overnight at $37^{\circ} \mathrm{C}$. Several colonies were picked up and suspended in $200 \mu \mathrm{l}$ of sterile deionized water in a $1.5 \mathrm{ml}$ Eppendorf tube. A bacterial suspension was made by using a vortex and then boiled at $95^{\circ} \mathrm{C}$ for $15 \mathrm{~min}$. After centrifugation at $10,000 \mathrm{~g}$ for $5 \mathrm{~min}$, the supernatant used as template DNA for PCR. 


\section{Polymerase Chain Reaction (pcr)}

Conventional PCR was performed for the detection of bla $\mathrm{CTX}-M-1_{1}$ gene. Amplification was carried out in a thermocycler (TECHNE/TC-312, UK), using CTX-M-1 group-specific primer; CTX-MA-1 5'-

SCSATGTGCAGYACCAGTAA-3' and CTX-MA-2 5'-CCGCRATATGRTTGGTGGTG-3', [22] (where $S$ is $G$ or C, Y is $\mathrm{C}$ or $\mathrm{T}$, and $\mathrm{R}$ is $\mathrm{A}$ or $\mathrm{G}$ ) (Macrogen, Korea). The following reaction mixtures were used in a volume of $25 \mu \mathrm{l} ; 5 \mu \mathrm{l}$ Master mix (iNtRON Biotechnology, Seongnam, Korea), $0.6 \mu \mathrm{l}$ of forward primer, $0.6 \mu \mathrm{l}$ of reverse primer ( $10 \mathrm{pmol} / \mu \mathrm{L}), 2 \mu \mathrm{LNA}$ and $16.8 \mu \mathrm{l}$ deionized sterile water. This mixture then underwent initial denaturation step at $94^{\circ} \mathrm{C}$ for $5 \mathrm{~min}$, then proceeded by 30 cycles of denaturation at $94^{\circ} \mathrm{C}$ for 45 seconds, primer annealing at $57^{\circ} \mathrm{C}$ for 45 seconds, and elongation at $72{ }^{\circ} \mathrm{C}$ for 60 seconds. A final elongation step accomplished at $72{ }^{\circ} \mathrm{C}$ for 5 minutes. Five microliters of the products were examined on a $2.0 \%$ agarose gel in TBE $1 \mathrm{X}$ containing $2.5 \mu \mathrm{l}$ of $(20 \mathrm{mg} / \mathrm{ml})$ ethidium bromide, using the electrophoresis apparatus at $100 \mathrm{~V}$ for $40 \mathrm{~min}$. Band size was visualized under U.V transilluminator (UVitec, UK) and compared to 100 base pairs (bp) standard DNA ladder (Fig. 1).

\section{Statistics Analysis}

Data were analyzed by using statistical package for the Social Sciences (SPSS) version 20. Chi-squared test performed to find the probable relationship between variables, $p$-value $<.05$ was considered statistically significant.

\section{Results}

\section{Isolation of bacteria}

In the present study, a total of two hundred and eighty water samples were collected from Khartoum State localities (145 from Khartoum locality, 70 from Khartoum North and 65 from Omdurman locality).

From 280 water samples, 86 (30.7\%) E. coli were isolated, they are distributed as follows: In Khartoum locality $29 \%$ (42/145), in Khartoum North locality $29 \%$ (20/70), and in Omdurman locality $37 \%(24 / 65)$.

From 280 water samples, 160 were from taps water, and 120 were from tanks water, 29\% (47/160), and $33 \%(39 / 120)$ of taps and tanks water were positive for $E$. coli, respectively. Out of 86 isolates, $49 \%$ (42/86) were from Khartoum, 28\% (24/86) were from Omdurman, and 23\% (20/86) were from Khartoum North locality. And 55\% (47/86) were from taps water, and $45 \%(39 / 86)$ were from water tanks.

\section{Antimicrobial Susceptibility}

All E. coli isolates (86) were subjected to antimicrobial susceptibility testing by the disc diffusion technique. The results have shown that $20 \%(17 / 86)$ of all isolates were resistant to cefotaxime, $35 \%$ 
(30/86) were resistant to gentamicin, 59\% (51/86) were resistant to tetracycline, and $22 \%(19 / 86)$ were resistant to chloramphenicol (Table 1).

\section{Detection of the bla $\mathrm{CTX}-\mathrm{M}-1$ gene by PCR}

Out of $86 \mathrm{E}$. coli isolates subjected to PCR for the detection of bla ${ }_{C T X-M-1}$ gene, $40 \%$ (34/86) were positive. Among them, 31\% (13/42) were from Khartoum locality, 55\% (11/20) were from Khartoum North, and $42 \%(10 / 24)$ were from Omdurman locality. Eighteen were from tap water, and 16 were from tanks. From 34 bla $_{C T X-M-1}$ positive isolates, $38 \%$ (18/47) were from taps water, and $41 \%(16 / 39)$ were from tanks water (Table 2).

There was no statistically significant association between the presence of bla $\mathrm{CTX}-M-1_{1}$ gene and different variables (Khartoum State localities, sources of water samples, and antimicrobials susceptibility) ( $p$ value $>0.05)$.

Table 1

Association of bla ${ }_{C T X-M-1}$ gene and antimicrobial susceptibility testing

\begin{tabular}{|c|c|c|c|c|c|c|c|c|}
\hline \multirow[t]{2}{*}{ CTX-M-1 gene } & \multicolumn{2}{|c|}{ Cefotaxime } & \multicolumn{2}{|c|}{ Gentamicin } & \multicolumn{2}{|c|}{ Tetracycline } & \multicolumn{2}{|c|}{ Chloramphenicol } \\
\hline & $S$ & $\mathbf{R}$ & $S$ & $\mathbf{R}$ & $S$ & $\mathbf{R}$ & $S$ & $\mathbf{R}$ \\
\hline Positive $(n=34)$ & 26 & 8 & 20 & 14 & 12 & 22 & 28 & 6 \\
\hline Negative $(n=52)$ & 43 & 9 & 36 & 16 & 23 & 29 & 39 & 13 \\
\hline Total $(n=86)$ & 69 & 17 & 56 & 30 & 35 & 51 & 67 & 19 \\
\hline$p$-value & 0.3 & & 0.08 & & 0.4 & & 0.4 & \\
\hline
\end{tabular}

Table 2

Distribution of blaCTX-M-1 gene according to the area of water samples

\begin{tabular}{|llllll|}
\hline CTX-M-1 gene & \multicolumn{2}{l}{ Locality } & \multicolumn{3}{l|}{ Water source } \\
\cline { 2 - 6 } & Khartoum & Omdurman & Khartoum North & Tap water & Tanks \\
\hline Positive $(\mathrm{n}=34)$ & 13 & 10 & 11 & 18 & 16 \\
\hline Negative $(\mathrm{n}=52)$ & 29 & 14 & 9 & 29 & 23 \\
\hline Total $(\mathrm{n}=86)$ & 42 & 24 & 20 & 47 & 39 \\
\hline$p$-value & 0.188 & & & 0.485 & \\
\hline
\end{tabular}

\section{Discussion}


According to the recommendations by the world health organization [23], detection of E. coli in drinking water used as an indicator for testing water quality and fecal contamination. In this study, $30.7 \%$ $(86 / 280)$ isolates of $E$. coli were detected in the drinking water of Khartoum State; this might be due to the probable fecal contamination of Khartoum state drinking water [24], and the absence or inefficient of the pre-distribution water treatment.

In the present study, we detected a high prevalence of bla $\mathrm{CTX}_{\mathrm{T}-\mathrm{M}-1}$ gene in E. coli water isolates (40\%). This finding is more than previous reports in Northern Tanzania; they found that the CTX-M gene was present in $17.7 \%$ of $E$. coli isolated from drinking water [25]. And in China, a study conducted by Gao et al. reported $14.8 \%$ of ESBL-producing E. coli from downstream water [26]. Furthermore, in South Africa, Muringani et al. found that $28 \%(18 / 65)$ of water samples were positive for CTX-M [27]. The high prevalence of bla $\mathrm{CTX}-M-1_{-1}$ carrier E. coli in Khartoum State drinking water could be one of the main reasons for the dissemination of CTX-M positive isolated in Khartoum State [10-12].

Although cefotaxime is one of the cephalosporins which can hydrolyze by CTX-M gene, this study showed that $77 \%$ (26/34) of cefotaxime sensitive isolates were positive for CTX-M gene. This finding may be due to a lack of or a low level of expression of CTX-M gene in our isolates [28, 29]. This finding agrees with Muringani et al. they found that from 65 water samples, 18 were positive for CTX-M, and all samples were sensitive to cefotaxime [27].

Moreover, the present study showed that there was a high resistance rate (59\%) to tetracycline compared with the other antimicrobial used in this study. This result entirely disagrees with Adesoji and Ogunjobi [30], who reported that the resistance to tetracycline was $29 \%$ of Gram-negative bacteria isolated from drinking water in Nigeria, and other studies reported less resistant rate of tetracycline for $E$. coli isolated from surface waters. For instance, Nontongana et al. [31] reported $13 \%$ of tetracycline-resistant for $E$. coli recovered from the Kat River in South Africa. Rashid et al., [13] found that all of the E. coli isolates from water were resistant to at least one or more classes of antimicrobials, and the most common resistant phenotypes were to ampicillin, tetracycline. This difference in resistance may be due to differences in the study area and sample size.

\section{Conclusions}

This study for the first time reported the presence of the antimicrobial-resistant gene (CTX-M group one) in E. coli isolated from drinking water, in Khartoum State. Furthermore, drinking water in Khartoum State may be contaminated with faces and might be a source of transmission of antimicrobials resistant genes. Health workers need to be aware of the spread of antibiotic-resistant bacteria through drinking water. They should improve the process of water filtration.

\section{Declarations}




\section{Consent for publication}

Not applicable.

\section{Availability of data and materials}

Data is available from corresponding author upon request

\section{Ethics approval and consent to participate}

The research was approved by institutional ethics committee of deanship of scientific research, Sudan University of Science and Technology No: DSR-IEC3-03-07.

\section{Conflict of Interests}

All the authors declare no conflict of interest.

\section{Competing interests}

The authors declare that they have no competing interests.

\section{Funding}

This project was funded by the Deanship of Scientific Research (DSR), King Abdulaziz University, Jeddah, Kingdom of Saudi Arabia under grant No. D-569-130-1441.

\section{Authors' contributions}

HNA, and EKS, EHM designed the study, EKS and HNA performed the experiments, HNA, and EHM analyzed the data, HNA, EHM, and EKS wrote the manuscript, all the authors approved the final version of the manuscript.

\section{Acknowledgments}

The authors would like to thanks the staff of Microbiology lab, College of Medical Laboratory Science, Sudan University of Science and Technology for their support during this study. Also the authors thanks Dr. Nouraldeen the head of microbiology department in laboratory adminstration of Khartoum State, for supporting in samples collection. 


\section{References}

1. Organization WH: Antimicrobial resistance: global report on surveillance: World Health Organization; 2014.

2. Peters L, Olson L, Khu DT, Linnros S, Le NK, Hanberger H, Hoang NT, Tran DM, Larsson M. Multiple antibiotic resistance as a risk factor for mortality and prolonged hospital stay: A cohort study among neonatal intensive care patients with hospital-acquired infections caused by gram-negative bacteria in Vietnam. PloS one 2019, 14;5.

3. Njage PMK, Buys EM. Pathogenic and commensal Escherichia coli from irrigation water show potential in transmission of extended spectrum and AmpC $\beta$-lactamases determinants to isolates from lettuce. Microb Biotechnol. 2015;8:3:462-73.

4. Ali T, Ali I, Khan NA, Han B, Gao J: The growing genetic and functional diversity of extended spectrum beta-lactamases. BioMed research international 2018, 2018.

5. Hall BG, Barlow M. Revised Ambler classification of $\beta$-lactamases. J Antimicrob Chemother. 2005;55:6:1050-51.

6. lovleva A, Bonomo RA. The ecology of extended-spectrum $\beta$-lactamases (ESBLs) in the developed world. Journal of travel medicine. 2017;24;suppl_1:44-51.

7. Guiral E, Pons MJ, Vubil D, Marí-Almirall M, Sigaúque B, Soto SM, Alonso PL, Ruiz J, Vila J, Mandomando I. Epidemiology and molecular characterization of multidrug-resistant Escherichia coli isolates harboring blaCTX-M group 1 extended-spectrum $\beta$-lactamases causing bacteremia and urinary tract infection in Manhiça, Mozambique. Infection and drug resistance 2018, 11927.

8. Peerayeh SN, Eslami M, Memariani M, Siadat SD. High prevalence of blaCTX-M-1 group extendedspectrum $\beta$-lactamase genes in Escherichia coli isolates from Tehran. Jundishapur Journal of Microbiology 2013, 6;7.

9. Pavez M, Troncoso C, Osses I, Salazar R, Illesca V, Reydet P, Rodríguez C, Chahin C, Concha C, Barrientos L. High prevalence of CTX-M-1 group in ESBL-producing enterobacteriaceae infection in intensive care units in southern Chile. The Brazilian Journal of Infectious Diseases. 2019;23(2):10210.

10. Altayb HN, Siddig MA, El Amin NM, Maowia AlH, Mukhtar M. Molecular Characterization of CTX-M ESBLs among Pathogenic Enterobacteriaceae isolated from different regions in Sudan. Global Advanced Research Journal of Microbiology (GARJM). 2018;7:040-47.

11. Osman HSA: Evaluation of Multi-drug Resistant Echerichia coli Isolated from Patients with Urinary Tract Infection and Phylogenetic Analysis of CTX-M Gene, In Om-Algora locality, Gezira State, Sudan (2017). University of Gezira; 2018.

12. Malik I, Elhag K. Characterisation of Extended-Spectrum $\beta$-Lactamases Among Multidrug Resistant Enterobacteriaceae From Sudan. J Pure Appl Microbiol. 2019;13;1:61-8.

13. Rashid M, Rakib MM, Hasan B. Antimicrobial-resistant and ESBL-producing Escherichia coli in different ecological niches in Bangladesh. Infection Ecology Epidemiology. 2015;5:1:26712. 
14. Rizzo L, Manaia C, Merlin C, Schwartz T, Dagot C, Ploy MC, Michael I, Fatta-Kassinos D. Urban wastewater treatment plants as hotspots for antibiotic resistant bacteria and genes spread into the environment: a review. Sci Total Environ. 2013;447:345-60.

15. Coleman BL, Salvadori MI, McGeer AJ, Sibley KA, Neumann NF, Bondy SJ, Gutmanis IA, McEwen SA, Lavoie $M$, Strong $D$, et al. The role of drinking water in the transmission of antimicrobial-resistant $E$. coli. Epidemiol Infect. 2012;140:4:633-42.

16. Coleman BL, Louie M, Salvadori MI, McEwen SA, Neumann N, Sibley K, Irwin RJ, Jamieson FB, Daignault D, Majury A, et al. Contamination of Canadian private drinking water sources with antimicrobial resistant Escherichia coli. Water Res. 2013;47:9:3026-36.

17. Sanganyado E, Gwenzi W. Antibiotic resistance in drinking water systems: Occurrence, removal, and human health risks. Science of the Total Environment 2019.

18. Bumadian MM, Almansury HH, Bozakouk IH, Lawgali YF, Bleiblo FA. Detection and Enumeration of Coliform Bacteria in Drinking Water at Hospital of Benghazi/Libya. Journal of Experimental Biology 2013, 16.

19. Bartram J, Ballance R: Water quality monitoring: a practical guide to the design and implementation of freshwater quality studies and monitoring programmes: CRC Press; 1996.

20. CLSI C. Performance standards for antimicrobial susceptibility testing. Clinical Lab Standards Institute 2016.

21. Al-Gallas N, Ben Aissa RR, Attia Annabi T, Bahri O, Boudabous A. Isolation and characterization of shiga toxin-producing Escherichia coli from meat and dairy products. Food Microbiol. 2002;19:4:389-98.

22. Saladin M, Cao VTB, Lambert T, Donay J-L, Herrmann J-L, Ould-Hocine Z, Verdet C, Delisle F, Philippon A, Arlet G. Diversity of CTX-M $\beta$-lactamases and their promoter regions from Enterobacteriaceae isolated in three Parisian hospitals. FEMS Microbiol Lett. 2002;209(2):161-68.

23. WHO WHO. Acute diarrhea in adults and children: a global perspective. World Gastroenterology Organization Global, 2012, Guidelines February 2012.

24. Alraheem MAAA. Pollution in the water supply wells of Khartoum, Sudan. Bull Eng Geol Env. 2000;58:4:257-64.

25. Lyimo B, Buza J, Subbiah M, Smith W, Call DR. Comparison of antibiotic resistant Escherichia coli obtained from drinking water sources in northern Tanzania: a cross-sectional study. BMC Microbiol. 2016;16:1:254.

26. Gao L, Hu J, Zhang X, Ma R, Gao J, Li S, Zhao M, Miao Z, Chai T. Dissemination of ESBL-producing Escherichia coli of chicken origin to the nearby river water. J Mol Microbiol Biotechnol. 2014;24:4:279-85.

27. Muringani B, Nziramasanga TA. P: $\beta$-lactamase Genes Produced by E. coli Isolated from Water and Stool Samples in Mthata Region Eastern Cape Province of South Africa. EC Microbiology. 2016;3:548-52. 
28. Kjeldsen TS, Overgaard M, Nielsen SS, Bortolaia V, Jelsbak L, Sommer M, Guardabassi L, Olsen JE. CTX-M-1 $\beta$-lactamase expression in Escherichia coli is dependent on cefotaxime concentration, growth phase and gene location. J Antimicrob Chemother. 2015;70:1:62-70.

29. Cantón R, González-Alba JM, Galán JC. CTX-M enzymes: origin and diffusion. Frontiers in microbiology 2012, 3110.

30. Adesoji AT, Ogunjobi AA. Detection of Extended Spectrum Beta-Lactamases Resistance Genes among Bacteria Isolated from Selected Drinking Water Distribution Channels in Southwestern Nigeria. BioMed research international 2016, 20167149295.

31. Nontongana N, Sibanda T, Ngwenya E, Okoh Al. Prevalence and antibiogram profiling of Escherichia coli pathotypes isolated from the Kat River and the Fort Beaufort abstraction water. Int J Environ Res Public Health. 2014;11:8:8213-27.

\section{Figures}

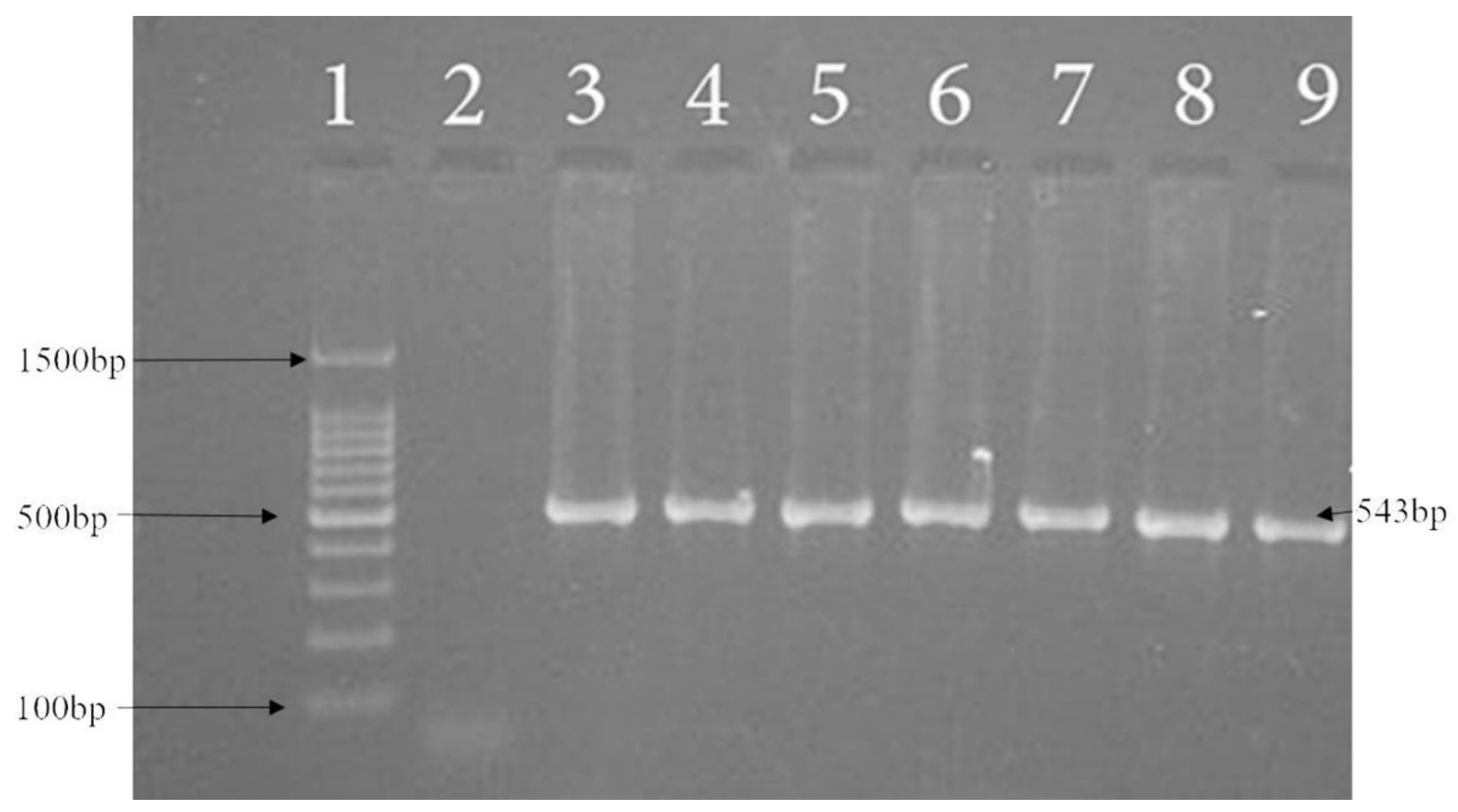

Figure 1

PCR amplification of the blaCTX-M-1 gene on $2 \%$ agarose gel electrophoresis. Lane 1 DNA ladder: MW 100-1500bp fragments. Lane 2 negative control (DW). Lanes 3 to 9 are positive (543 bp) samples. 